\title{
Phytoprotection
}

\section{The biology, damage and within-tree distribution on the spruce bud midge on black spruce in Newfoundland}

\section{R. J. West}

Volume 71, numéro 1, 1990

URI : https://id.erudit.org/iderudit/705980ar

DOI : https://doi.org/10.7202/705980ar

Aller au sommaire du numéro

Éditeur(s)

Société de protection des plantes du Québec (SPPQ)l

ISSN

0031-9511 (imprimé)

1710-1603 (numérique)

Découvrir la revue

Citer cet article

West, R. J. (1990). The biology, damage and within-tree distribution on the spruce bud midge on black spruce in Newfoundland. Phytoprotection, 71(1), 31-36. https://doi.org/10.7202/705980ar

\section{Résumé de l'article}

La cécidomyie de l'épinette (Rhabdophaga swainei) n'a qu'une seule génération par année sur l'épinette noire (Picea mariana) à Terre-Neuve. Les larves nouvellement écloses pénètrent dans les ébauches de bourgeons des nouvelles pousses à la fin de juin et au début de juillet; les larves, qui arrivent à maturité à l'automne, passeront l'hiver dans ces bourgeons. Elles s'y transformeront en pupes au printemps suivant et des adultes en émergeront en juin. Le nombre moyen d'oeufs trouvés dans des femelles vierges disséquées était de 86. Les parasites Platygaster rhabdophagae, Mesopolobus sp., Torymus $s p$. et Tetrastichus $s p$. ont été trouvés en grand nombre. Les bourgeons terminaux étaient beaucoup plus ravagés que les bourgeons latéraux ou latéraux supérieurs ; le tiers supérieur de la cime contenait également un plus grand nombre de bourgeons infestés mais sans pour autant affecter l'aspect de la cime. Les bourgeons infestés n'ont pas débourré et leur méristème apical ne s'est pas développé. L'allongement des cellules de l'ébauche de bourgeon est modifié par la présence de la cécidomyie de l'épinette qui produit des galles, sources d'éléments nutritifs et de protection pour les larves pendant l'hiver. Si le bourgeon d'une pousse apicale est attaqué, un bourgeon accessoire deviendra dominant et formera la nouvelle pousse apicale. Cette période de transition ralentit légèrement l'accroissement en hauteur mais la pousse apicale reprendra sa croissance normale au cours de l'année suivante. 


\title{
The biology, damage and within-tree distribution of the spruce bud midge on black spruce in Newfoundland
}

\author{
R.J. West \\ Forestry Canada, Newfoundland and Labrador Region, \\ P.O. Box 6028, St. John's, Newfoundland, Canada AlC $5 X 8$
}

(Received 1989-06-21; accepted 1989-11-06)

\begin{abstract}
The spruce bud midge (Rhabdophaga swainei) has one generation a year on black spruce (Picea mariana) in Newfoundland. Newly hatched larvae enter primordia of flushing buds in late June and early July and larvae mature by fall to overwinter within buds. Pupation occurs within buds the following spring and adults emerge in June. Virgin females averaged 86 eggs upon dissection. Platygaster rhabdophagae, Mesopolobus sp., Torymus sp., and Tetrastichus sp. were responsible for high parasitism levels of spruce bud midge larvae. Terminal buds were attacked significantly more than lateral or uppermost lateral buds. The number of infested buds was significantly higher in the top third of the crown than in the bottom crown third, but was not significantly different among north, east, south and west crown exposures. The apical meristem never developed in infested buds, and these buds did not flush. The growth of bud primordial cells is redirected by $R$. swainei to produce gall tissues that provide nutrients and an overwintering shelter for the larva. Attack of the terminal leader causes a slight loss in height growth but normal leader growth resumes the following year.
\end{abstract}

West, R.J. 1990. The biology, damage and within-tree distribution of the spruce bud midge on black spruce in Newfoundland. PHYTOPROTECTION $71:$ 31-36.

La cécidomyie de l'épinette (Rhabdophaga swainei) n'a qu'une seule génération par année sur l'épinette noire (Picea mariana) à Terre-Neuve. Les larves nouvellement écloses pénètrent dans les ébauches de bourgeons des nouvelles pousses à la fin de juin et au début de juillet; les larves, qui arrivent à maturité à l'automne, passeront l'hiver dans ces bourgeons. Elles s'y transformeront en pupes au printemps suivant et des adultes en émergeront en juin. Le nombre moyen d'oeufs trouvés dans des femelles vierges disséquées était de 86 . Les parasites Platygaster rhabdophagae, Mesopolobus sp., Torymus sp. et Tetrastichus sp. ont été trouvés en grand nombre. Les bourgeons terminaux étaient beaucoup plus ravagés que les bourgeons latéraux ou latéraux supérieurs; le tiers supérieur de la cime contenait également un plus grand nombre de bourgeons infestés mais sans pour autant affecter l'aspect de la cime. Les bourgeons infestés n'ont pas débourré et leur méristème apical ne s'est pas développé. L'allongement des cellules de l'ébauche de bourgeon est modifié par la présence de la cécidomyie de l'épinette qui produit des galles, sources d'éléments nutritifs et de protection pour les larves pendant l'hiver. Si le bourgeon d'une pousse apicale est attaqué, un bourgeon accessoire deviendra dominant et formera la nouvelle pousse apicale. Cette période de transition ralentit légèrement l'accroissement en hauteur mais la pousse apicale reprendra sa croissance normale au cours de l'année suivante.

\section{Introduction}

The spruce bud midge, Rhabdophaga swainei Felt (Diptera: Cecidomyiidae), attacks all species of spruce throughout the boreal region of Canada (Cerezke 1972; Rose and Lindquist 1977). Trees may form multiple leaders when terminal buds of leaders are infested (Clark 1952; Ruth et al. 1982).

The life history of $R$. swainei has been described by Clark (1952) and Cerezke (1972). Females oviposit in flushing buds in late spring and newly hatched larvae bore into shoot tips. Larvae feed within developing buds throughout the summer and mature

$\overline{0031-9511 / 90} \$ 1.00+.10$ larvae overwinter in buds. Adults emerge from late April to early May. In Newfoundland, extensive multiple leadering has been observed in fire-regenerated stands of black spruce (Picea mariana [Mill.] B.S.P.) infested by the midge (Carter 1984). The economic importance of this tree species initiated studies to examine the biology of the midge and its damage. The life history, fecundity, parasites and within-tree distribution of the midge are described and its effect on bud development and leader growth are discussed.

\section{Materials and methods}

Study sites. Black spruce stands that regenerated naturally after a major forest fire in 1961 near Glenwood, Gander, and Carmanville, Newfoundland, were sam- 
pled. Trees in the stands were 1 to $4 \mathrm{~m}$ tall and 10 to 25 years old.

Midge biology. Infested buds were collected at Gander bi-weekly from May to July and monthly from August to October in 1984 and dissected to determine midge development and parasitism levels. To estimate fecundity, 30 virgin females collected from the field as pupae were dissected upon emergence and their eggs counted.

Within-tree distribution. The distribution of infested buds within the tree was defined according to vertical level (top, mid-, and bottom crown-thirds), crown exposure (north, east, south, and west) and bud position on the twig (terminal, uppermost lateral, and lateral). A bud was considered as an uppermost lateral if it was one of a group of distally located nodal buds subtending the terminal and as a lateral if it was clearly internodal. Buds intermediate between uppermost laterals and laterals were placed in the same category as the nearest identified bud.

Sampling was completed prior to bud flush in May and early June at Glenwood in 1985 and Carmanville in 1986. Twenty-five trees in each of three height classes ( 1 to $2 \mathrm{~m}, 2$ to $3 \mathrm{~m}$, and 3 to $4 \mathrm{~m}$ ) were examined in each year. In each tree, equal numbers of entire one-year-old shoots $(n=20$ in 1985, $\mathrm{n}=10$ in 1986) were removed from each of 12 sampling zones defined by the intersection of the four crown quadrants and three crown thirds. All current-year buds on the sampled shoots were dissected for midges or parasites. Numbers of buds examined, infested buds, and infested buds with parasites were totalled according to category on a per tree basis and transformed by $\log (x+1)($ Zar 1974) to obtain normally distributed data sets. Category means were compared by simple Anova and Duncan's multiple range test $(\alpha=0.05)$ (SAS Institute 1985).

Morphology of infested buds. The effect of the midge on bud development was determined by examining infested and uninfested terminal buds collected periodically from branches of black spruce at Gander in 1984-85. Buds were bisected longitudinally, fixed for 10 to $12 \mathrm{~h}$ in $6 \%$ glutaraldehyde in $0.2 \mathrm{M}$ phosphate buffer, dehydrated in a tertiary butyl alcohol series and embedded in Paraplast $^{\circledR}$. Serial $8 \mu \mathrm{m}$ sections were stained with hematoxylin and safranin (Johansen 1940).

Effect of midge infestation on leader growth. When the terminal leader bud is damaged, subordinate buds compete for dominance and eventually one becomes the new leader or dominant shoot. During this transition multiple leadering is present and the annual gain in leader growth is reduced. Leader growth over three years was compared between two groups of 30 trees of similar size at the Gander site which differed by having either a midge-infested or uninfested leader bud in 1984. Annual growth was measured after mid-August when the seasonal period of vertical growth of black spruce ceases in the Gander area (Khalil 1973).

\section{Results and discussion}

Midge biology. Midge development was similar to that described by Clark (1952). Pupation began in early May and all adults had emerged by the end of July with the majority emerging by the end of June. Immature midge larvae were present in primordial buds in July. Larvae entered their third instar (overwintering stage) by October. Parasitism of mature larvae in the spring of 1984 ranged from 31 to $44 \%$ depending on the date of collection, but did not prevent bud damage. Parasites of spruce bud midge larvae included two Mesopolobus spp. (Pteromalidae), Torymus sp. (Torymidae), Platygaster rhabdophagae MacGown (Platygastridae) and Tetrastichus sp. (Eulophidae). Although $P$. rhabdophagae has been described (MacGown 1979), taxonomic revisions are needed before the species of Torymus, Mesopolobus and Tetrastichus can be identified.

One-day-old virgin female midges had a mean of $86 \pm 6( \pm \mathrm{SE})$ eggs (range 16 to 139). Clark (1952) reported nine fully formed eggs in the oviduct of one adult female, but made no reference to its age, mated state and ovipositional history.

Within-tree distribution. Terminal buds were infested significantly more than other bud types at both sites and in all height classes (Table 1). Uppermost lateral buds 
were significantly more infested than lateral buds at the Carmanville site but not at Glenwood. More buds were attacked in the upper third of the crown of infested trees and significantly so at the Glenwood site. There were significantly more midge-infested buds in the middle crown than in the lower crown, but only on trees taller than $2 \mathrm{~m}$ at Glenwood (Table 2).

The number of midge-infested buds showed a weak trend of increasing with height but differences between height classes were seldom significant. There was no significant difference in the amount of infestation between the four crown exposures, however, there were always more infested buds sampled on the south side than the north side. Considering that most of the trees were growing in open sites, this was not surprising.

The distribution of midge parasites within the tree generally followed that of their hosts. Infested buds with parasites were more plentiful in terminal bud positions and in the upper third of the crown.

These results partly support those of Cerezke (1972) who found that the amount of infestation was highest on terminal buds, increased with tree height and was greater on the south rather than the north side. Similar within-tree distribution was also described for the pine needle gall midge, Thecodiplosis japonensis Uchida and Inouye (Soné 1985).

Morphology of infested buds. By late July, the terminal apex of uninfested primordial buds differentiated into an apical zone, peripheral zone, and rib meristem containing densely staining substances (Fig. 1A) as previously described for Englemann spruce (Picea engelmannii Parry) by Harrison and Owens (1983). In midge-infested primordial buds, the terminal apex lacks distinct zonation but cells are mitotically

Table 1. Incidence of buds infested by the spruce bud midge and infested buds with parasites sampled in three height classes and according to bud position on twigs of black spruce at Glenwood and Carmanville, Newfoundland, in 1985 and 1986, respectively

\begin{tabular}{|c|c|c|c|c|}
\hline \multirow[b]{3}{*}{ Bud category } & \multirow{3}{*}{$\begin{array}{c}\text { Height } \\
\text { class } \\
(\mathrm{m}) \\
\end{array}$} & \multicolumn{3}{|c|}{ Mean number of buds per tree $\S$} \\
\hline & & \multicolumn{3}{|c|}{ Bud position on twig } \\
\hline & & Terminal & $\begin{array}{l}\text { Uppermost } \\
\text { lateral }\end{array}$ & Lateral \\
\hline \multicolumn{5}{|l|}{1985 - Glenwood } \\
\hline Buds counted & $\begin{array}{l}1-2 \\
2-3 \\
3-4\end{array}$ & $\begin{array}{l}240.0 \mathrm{a}, \mathrm{A} \\
240.0 \mathrm{a}, \mathrm{A} \\
240.0 \mathrm{a}, \mathrm{A}\end{array}$ & $\begin{array}{l}205.5 \text { b,A } \\
258.2 \text { a,B } \\
277.6 \text { a,B }\end{array}$ & $\begin{array}{r}75.7 \mathrm{c}, \mathrm{A} \\
140.5 \mathrm{~b}, \mathrm{~B} \\
188.8 \mathrm{~b}, \mathrm{C}\end{array}$ \\
\hline Infested buds & $\begin{array}{l}1-2 \\
2-3 \\
3-4\end{array}$ & $\begin{array}{l}3.1 \mathrm{a}, \mathrm{A} \\
5.7 \mathrm{a}, \mathrm{B} \\
5.0 \mathrm{a}, \mathrm{B}\end{array}$ & $\begin{array}{l}0.3 \mathrm{~b}, \mathrm{~A} \\
0.6 \mathrm{~b}, \mathrm{~A} \\
0.5 \mathrm{~b}, \mathrm{~A}\end{array}$ & $\begin{array}{l}0.1 \mathrm{~b}, \mathrm{~A} \\
0.4 \mathrm{~b}, \mathrm{~A} \\
0.5 \mathrm{~b}, \mathrm{~A}\end{array}$ \\
\hline Parasitized buds & $\begin{array}{l}1-2 \\
2-3 \\
3-4\end{array}$ & $\begin{array}{l}1.2 \mathrm{a}, \mathrm{A} \\
1.4 \mathrm{a}, \mathrm{A} \\
1.8 \mathrm{a}, \mathrm{A}\end{array}$ & $\begin{array}{ll}0 & \mathrm{~b}, \mathrm{~A} \\
0.1 & \mathrm{~b}, \mathrm{~A} \\
0.1 & \mathrm{~b}, \mathrm{~A}\end{array}$ & $\begin{array}{l}0.1 \text { b, A } \\
0 \quad \text { b,A } \\
0.1 \text { b,A }\end{array}$ \\
\hline \multicolumn{5}{|c|}{1986 - Carmanville } \\
\hline Buds counted & $\begin{array}{l}1-2 \\
2-3 \\
3-4\end{array}$ & $\begin{array}{l}120.0 \mathrm{~b}, \mathrm{~A} \\
120.0 \mathrm{~b}, \mathrm{~A} \\
120.0 \mathrm{~b}, \mathrm{~A}\end{array}$ & $\begin{array}{l}223.7 \mathrm{a}, \mathrm{A} \\
233.9 \mathrm{a}, \mathrm{A} \\
211.8 \mathrm{a}, \mathrm{A}\end{array}$ & $\begin{array}{l}156.0 \mathrm{~b}, \mathrm{~A} \\
127.8 \mathrm{~b}, \mathrm{AB} \\
115.2 \mathrm{c}, \mathrm{B}\end{array}$ \\
\hline Infested buds & $\begin{array}{l}1-2 \\
2-3 \\
3-4\end{array}$ & $\begin{array}{l}3.8 \mathrm{a}, \mathrm{A} \\
5.2 \mathrm{a}, \mathrm{A} \\
5.0 \mathrm{a}, \mathrm{A}\end{array}$ & $\begin{array}{l}2.0 \mathrm{~b}, \mathrm{~A} \\
2.4 \mathrm{~b}, \mathrm{~A} \\
1.6 \mathrm{~b}, \mathrm{~A}\end{array}$ & $\begin{array}{l}0.9 \mathrm{c}, \mathrm{A} \\
0.8 \mathrm{c}, \mathrm{A} \\
0.7 \mathrm{c}, \mathrm{A}\end{array}$ \\
\hline Parasitized buds & $\begin{array}{l}1-2 \\
2-3 \\
3-4\end{array}$ & $\begin{array}{l}2.0 \mathrm{a}, \mathrm{A} \\
2.7 \mathrm{a}, \mathrm{A} \\
2.5 \mathrm{a}, \mathrm{A}\end{array}$ & $\begin{array}{l}1.3 \mathrm{ab}, \mathrm{A} \\
1.1 \mathrm{~b}, \mathrm{~A} \\
1.0 \mathrm{~b}, \mathrm{~A}\end{array}$ & $\begin{array}{l}0.6 \mathrm{~b}, \mathrm{~A} \\
0.5 \mathrm{~b}, \mathrm{~A} \\
0.4 \mathrm{~b}, \mathrm{~A}\end{array}$ \\
\hline
\end{tabular}

$\S$ Means of data are not significantly different $(P<0.05)$ according to Duncan's multiple range test if followed by the same letter within the same year and bud category. Mean groupings within height classes but between bud position on twig are indicated by lowercase letters. Uppercase letters indicate groupings within bud position but between height classes. Analysis was performed on transformed data $[\log (x+1)]$. 
Table 2. Incidence of buds infested by the spruce bud midge, and infested buds with parasites sampled in three height classes and according to crown level of black spruce at Glenwood and Carmanville, Newfoundland, in 1985 and 1986, respectively

\begin{tabular}{|c|c|c|c|c|}
\hline \multirow[b]{3}{*}{ Bud category } & \multirow{3}{*}{$\begin{array}{l}\text { Height } \\
\text { class } \\
\text { (m) }\end{array}$} & \multicolumn{3}{|c|}{ Mean number of buds per tree $\S$} \\
\hline & & \multicolumn{3}{|c|}{ Crown level (third) } \\
\hline & & Top & Mid & Bottom \\
\hline \multicolumn{5}{|l|}{1985 - Glenwood } \\
\hline Buds counted & $\begin{array}{l}1-2 \\
2-3 \\
3-4\end{array}$ & $\begin{array}{l}211.8 \text { a,A } \\
300.8 \text { a,B } \\
344.2 \text { a,C }\end{array}$ & $\begin{array}{l}164.5 \mathrm{~b}, \mathrm{~A} \\
178.5 \mathrm{~b}, \mathrm{AB} \\
192.7 \mathrm{~b}, \mathrm{~B}\end{array}$ & $\begin{array}{l}144.8 \mathrm{c}, \mathrm{A} \\
159.4 \mathrm{c}, \mathrm{AB} \\
171.3 \mathrm{~b}, \mathrm{~B}\end{array}$ \\
\hline Infested buds & $\begin{array}{l}1-2 \\
2-3 \\
3-4\end{array}$ & $\begin{array}{l}2.5 \mathrm{a}, \mathrm{A} \\
4.8 \mathrm{a}, \mathrm{B} \\
3.9 \mathrm{a}, \mathrm{B}\end{array}$ & $\begin{array}{l}0.6 \mathrm{~b}, \mathrm{~A} \\
1.4 \mathrm{~b}, \mathrm{~B} \\
1.4 \mathrm{~b}, \mathrm{~B}\end{array}$ & $\begin{array}{l}0.3 \mathrm{~b}, \mathrm{~A} \\
0.4 \mathrm{c}, \mathrm{A} \\
0.6 \mathrm{c}, \mathrm{A}\end{array}$ \\
\hline Parasitized buds & $\begin{array}{l}1-2 \\
2-3 \\
3-4\end{array}$ & $\begin{array}{l}1.0 \mathrm{a}, \mathrm{A} \\
1.0 \mathrm{a}, \mathrm{A} \\
1.2 \mathrm{a}, \mathrm{A}\end{array}$ & $\begin{array}{l}0.2 \mathrm{~b}, \mathrm{~A} \\
0.4 \mathrm{~b}, \mathrm{AB} \\
0.6 \mathrm{~b}, \mathrm{~B}\end{array}$ & $\begin{array}{l}0.1 \mathrm{~b}, \mathrm{~A} \\
0.1 \mathrm{~b}, \mathrm{~A} \\
0.6 \mathrm{~b}, \mathrm{~A}\end{array}$ \\
\hline \multicolumn{5}{|c|}{1986 - Carmanville } \\
\hline Buds counted & $\begin{array}{l}1-2 \\
2-3 \\
3-4\end{array}$ & $\begin{array}{l}201.4 \mathrm{a}, \mathrm{A} \\
190.1 \mathrm{a}, \mathrm{A} \\
187.6 \mathrm{a}, \mathrm{A}\end{array}$ & $\begin{array}{l}159.8 \mathrm{~b}, \mathrm{~A} \\
161.0 \mathrm{~b}, \mathrm{~A} \\
133.2 \mathrm{~b}, \mathrm{~B}\end{array}$ & $\begin{array}{l}138.5 \mathrm{c}, \mathrm{A} \\
130.6 \mathrm{c}, \mathrm{A} \\
129.8 \mathrm{~b}, \mathrm{~A}\end{array}$ \\
\hline Infested buds & $\begin{array}{l}1-2 \\
2-3 \\
3-4\end{array}$ & $\begin{array}{l}3.2 \mathrm{a}, \mathrm{A} \\
3.6 \mathrm{a}, \mathrm{A} \\
3.5 \mathrm{a}, \mathrm{A}\end{array}$ & $\begin{array}{l}2.5 \mathrm{a}, \mathrm{A} \\
2.9 \mathrm{a}, \mathrm{A} \\
2.5 \mathrm{a}, \mathrm{A}\end{array}$ & $\begin{array}{l}1.0 \mathrm{~b}, \mathrm{~A} \\
1.9 \mathrm{~b}, \mathrm{~A} \\
1.4 \mathrm{~b}, \mathrm{~A}\end{array}$ \\
\hline Parasitized buds & $\begin{array}{l}1-2 \\
2-3 \\
3-4 \\
\end{array}$ & $\begin{array}{l}1.7 \mathrm{a}, \mathrm{A} \\
1.7 \mathrm{ab}, \mathrm{A} \\
2.1 \mathrm{a}, \mathrm{A} \\
\end{array}$ & $\begin{array}{l}1.6 \mathrm{a}, \mathrm{A} \\
1.8 \mathrm{a}, \mathrm{A} \\
1.2 \mathrm{a}, \mathrm{A}\end{array}$ & $\begin{array}{l}0.6 \mathrm{~b}, \mathrm{~A} \\
0.8 \mathrm{~b}, \mathrm{~A} \\
0.6 \mathrm{~b}, \mathrm{~A}\end{array}$ \\
\hline
\end{tabular}

$\S$ Means of data are not significantly different $(P>0.05)$ according to Duncan's multiple range test if followed by the same letter within the same year and bud category. Mean groupings within height classes but between crown levels are indicated by lower-case letters. Uppercase letters indicate groupings within crown levels but between height classes. Analysis was performed on transformed data $[\log (x+1)]$.

active, cytoplasmically dense and exhibit cytoplasmic stranding (Fig. 1B). These cells give rise to a distinct and densely staining nutritive zone (Rohfritsch and Shorthouse 1982) which sustains the growing larva throughout the summer (Fig. 1C). True primordial leaves and a normal rib meristem (Fig. 1D) never develop in infested buds, however leaf primordia develop into swollen inner bud scales which envelop the midge in a larval chamber (Fig. 1C).

By late fall the midge larva is mature and presumably ceases to feed. Infested buds collected during the winter had a reduced nutritive zone with collapsed cells nearest the larval chamber (Fig. 1E). A hard layer of tissue, probably containing phenolic substances, forms next to the receding nutritive zone and may help to protect the larva during the winter (Fig. 1E).

There is little change in the morphology of infested buds prior to the emergence of the adult midge in late spring but inner bud scales may swell and assume the appearance of a pink-edged rosette. Infested buds do not flush and there is no shoot elongation because an apical meristem never develops.

Under the criteria of Rohfritsch and Shorthouse (1982), buds infested by the spruce bud midge can be considered as galled because an insect has redirected normal patterns of plant growth to the formation of new tissues that it uses to its own advantage.

Effect of midge infestation on leader growth. Mean tree heights ( \pm S.E.) in 1984 were $281.7 \pm 5.5 \mathrm{~cm}$ and $287.3 \pm 5.2 \mathrm{~cm}$ for the infested and uninfested groups, respectively. Respective mean diameters at breast height for both groups were $2.7 \pm 0.1 \mathrm{~cm}$. The trees with infested 1984 terminal leader buds had multiple leaders and significantly less dominant shoot growth than uninfested trees in 1984 (Table 

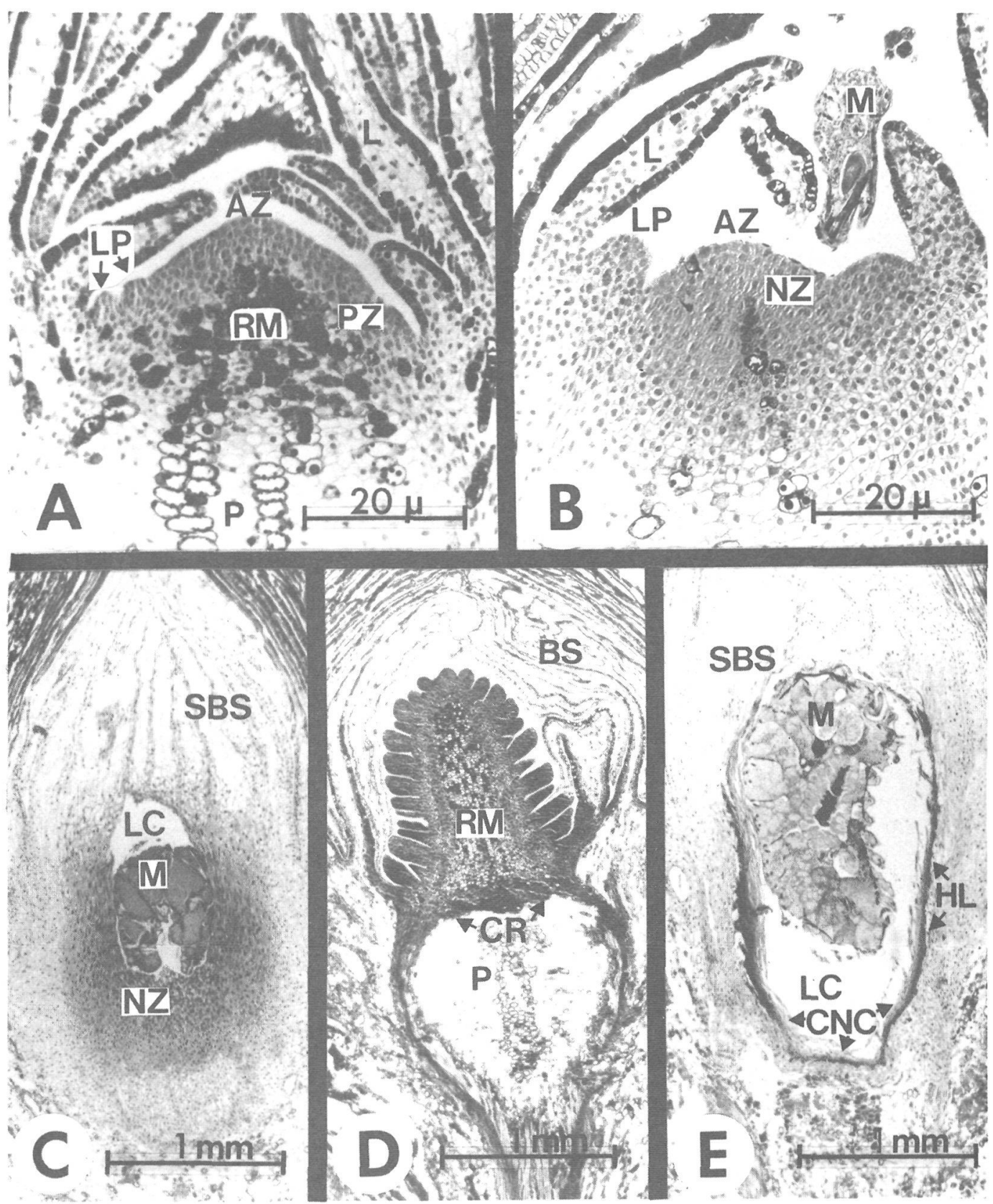

Figure 1. Median longitudinal sections of buds infested by Rhabdophaga swainei and uninfested buds. A. Recently differentiated terminal vegetative apex of an uninfested primordial bud collected in late July: apical zone (AZ), peripheral zone (PZ), rib meristem (RM) containing densely staining substances, leaf primordia (LP), basal leaves (L), and pith (P). B. A terminal vegetative apex of an infested primordial bud collected in late July: densely staining and stranded cells of the young nutritive zone (NZ), relatively undifferentiated apex and the midge larva (M). C. An infested bud collected in late September. Note prominent nutritive zone (NZ), swollen inner bud scales (SBS), larva (M), and larval chamber (LC). D. An uninfested bud collected in late October showing well developed leaf primordia, rib meristem (RM), crown region (CR), pith (P), and thin bud scales (BS). E. An infested bud collected in February showing a mature larva (M), collapsed nutritive cells (CNC), and a hard layer of tissue (HL). 
Table 3. A comparison of dominant shoot (leader) growth over three years between two groups of 30 black spruce trees with either midge-infested or undamaged leader buds in 1984

\begin{tabular}{|c|c|c|c|c|c|c|c|c|}
\hline \multirow{2}{*}{$\begin{array}{l}\text { Status of leader } \\
\text { bud in } 1984\end{array}$} & \multicolumn{3}{|c|}{$\begin{array}{l}\text { Trees with } \\
\text { midge-infested } \\
\text { leader buds } \\
(\%)\end{array}$} & \multicolumn{3}{|c|}{$\begin{array}{l}\text { Dominant shoot growth }(\mathrm{cm}) \\
\qquad(\bar{x} \pm \mathrm{SE})\end{array}$} & \multicolumn{2}{|c|}{$\begin{array}{l}\text { Cumulative dominant shoot } \\
\text { growth }(\mathrm{cm}) \text { from } 1984 \\
(\bar{x} \pm \mathrm{SE})\end{array}$} \\
\hline & 1984 & 1985 & 1986 & 1984 & 1985 & 1986 & 1985 & 1986 \\
\hline Midge-infested & 100 & 13 & 10 & $20.7 \pm 0.9 *$ & $16.6 \pm 0.9$ & $18.7 \pm 1.3$ & $37.3 \pm 1.4 *$ & $56.0 \pm 2.3$ \\
\hline Uninfested & 0 & 13 & 8 & $24.7 \pm 1.1 *$ & $18.6 \pm 0.9$ & $19.1 \pm 1.6$ & $42.7 \pm 1.7 *$ & $61.8 \pm 2.9$ \\
\hline
\end{tabular}

* Significant difference $(P<0.05)$ according to Student's t-test.

3). Cerezke (1972) simulated midge damage by removing the terminal leader buds of white spruce trees, prior to spring bud growth and observed a $25 \%$ loss in dominant shoot growth, slightly more than the $16 \%$ loss observed in the present study. The smaller growth loss in midge-infested trees might be explained by an earlier assumption of dominance by the bud destined to be the subsequent leader. In Cerezke's (1972) study, bud damage occurred in the spring whereas midge-infested buds are damaged as primordia the previous summer. Leader growth was not significantly different between infested and uninfested trees in 1985 nor in 1986 (Table 3). Cumulative leader growth from 1984 was significantly higher for the uninfested group in 1985 but not in 1986 which indicates that the effect of midge infestation was significant for only two years. Growth effects of a similar duration were also observed by Cerezke (1972) for artificially-damaged white spruce. In summary, host damage by the spruce bud midge appears to be confined to a small reduction in height growth when terminal leader buds are attacked.

I thank L. Durrouchel, L. Masner, C.M. Yoshimoto, and A. Borkent of the Biosystematics Research Institute for identifying specimens of the spruce bud midge and its parasites. Helpful comments on the manuscript were made by $\mathrm{H}$. Cerezke of the Northern Forestry Centre and W. Bowers of the Newfoundland Forestry Centre. D.S. Durling provided assistance in the field.

Carter, N.E. 1984. The occurrence of multiple leaders in spruce regeneration in Newfoundland caused by an insect suspected to be the spruce bud midge (Diptera: Cecidomyiidae - Rhabdophaga sp. prob. swainei Felt). Gov. of Newfoundland and Labrador, Dep. For. Resour. Lands. Inf. Rep. FP-8, 19 pp.
Cerezke, H.F. 1972. Observations on the distribution of the spruce bud midge (Rhabdophaga swainei Felt) in black and white spruce crowns and its effect on height growth. Can. J. For. Res. 2: 69-72.

Clark, J. 1952. The spruce bud midge, Rhabdophaga swainei Felt (Cecidomyiidae: Diptera). Can. Entomol. 84: 87-89.

Harrison, D.L.S., and J.N. Owens. 1983. Bud development in Picea engelmanii. I. Vegetative bud development, differentiation and early development of reproductive buds. Can. J. Bot. 61: 2291-2301.

Johansen, D.A. 1940. Plant microtechnique. McGraw-Hill Book Co. Inc., New York. 523 pp.

Khalil, M.A.K. 1973. Results of a four--year nursery provenance experiment on black spruce in Newfoundland. Environ. Can., Can. For. Serv., Inf. Rep. N-X-99, 76 pp.

MacGown, M.W. 1979. The Platygastridae (Hymenoptera: Proctotrupoidea) parasitic on midges (Cecidomyiidae) found on conifers in Canada and the United States. Miss. Agric. For. Exp. Stn., Inf. Bull. 9, 131 pp.

Rohfritsch, O., and J.D. Shorthouse. 1982. Insect galls. Pages 131-152 in G. Kahl and J.S. Schell (eds.), Molecular biology of plant tumors. Academic Press, New York.

Rose, A.H., and O.H. Lindquist. 1977. Insects of eastern spruces, fir and hemlock. Environ. Can., Can. For. Serv., For. Tech. Rep. 23, 159 pp.

Ruth, D.S., G.E. Miller, and J.R. Sutherland. 1982. A guide to insect pests and diseases in spruce seed orchards. Environ. Can., Can. For. Serv., Inf. Rep. BC-X-231, 26 pp.

SAS Institute. 1985. SAS user's guide: statistics. SAS Institute. Cary, N.C. 956 pp.

Soné, K. 1985. Within-tree distribution of the infestation by the pine needle midge, Thecodiplosis japonensis Uchida and Inouye (Diptera: Cecidomyiidae). J. Jpn. For. Soc. 67: 495-500.

Zar, J.H. 1974. Biostatistical analysis. Prentice-Hall, Inc., Englewood Cliffs, N.J. 620 pp. 